\title{
TINJAUAN HUKUM ISLAM TERHADAP PRAKTIK “DEREP PARI” DI DESA TINOMBALA BARAT
}

\author{
Yaumil Qodriyah ${ }^{1}$, Sapruddin $^{2}$, Abidin Djafar ${ }^{3}$ \\ ${ }^{1}$ Mahasiswa ${ }^{2,3}$ Dosen Fakultas Syariah Institut Agama Islam Negeri Palu \\ ymqodriyah@gmail.com
}

\begin{abstract}
This research focuses on the description of Islamic law relating to the practice of Derep Pari in West Tinombala Village, Ongaka Malino District, Parigi Mutong Regency, so that the formulation of questions that must be answered are (1) How is the description of the practice of Derep Pari in West Tinombala? (2) What is the law on derep pari in the village of West Tinombala according to Islamic law perspective? The results showed that (1) In the practice of Derep-Pari in Tinombala Barat Village, the wage system was determined by the agreement. (2) From the perspective of Islamic law, the wage system in Tinombala Barat Village is in accordance with Islamic law, where the principles and operational rules already include aspects of justice, because the wage paid to worker are given immediately after the work is completed and wage payment is in accordance with the agreement.
\end{abstract}

Keywords: Farmhand; Harvest; Islamic Law; Wages.

\begin{abstract}
Abstrak
Pembahasan penelitian ini difokuskan pada gambaran hukum Islam terkait dengan praktik Derep Pari di Desa Tinombala Barat, Kecamatan Ongaka Malino, Kabupaten Parigi Mutong, sehingga rumusan pertanyaan yang wajib terjawab adalah (1) Bagaimana gambaran tentang praktik Derep Pari di Tinombala Barat (2) Bagaimana hukum derep pari di desa Tinombala Barat dalam ajaran Islam. Hasil penelitian menunjukkan bahwa (1) Dalam praktik Derep-Pari di Desa Tinombala Barat, sistem pengupahan ditentukan berdasarkan hasil kesepakatan. (2) Dari perspektif hukum Islam, sistem pengupahan di Desa Tinombala Barat telah sesuai dengan hukum Islam, di mana prinsip dan ketentuan operasionalnya sudah mencakup aspek keadilan karena upah yang dibayarkan kepada buruh langsung diberikan setelah pekerjaannya selesai dan dalam pemberian upahnya sesuai dengan kesepakatan atau sesuai dengan perjanjian.
\end{abstract}

Kata kunci: Buruh Tani; Hukum Islam; Panen; Upah.

\section{A. PENDAHULUAN}

Upah adalah biaya pekerjaan yang wajib dibayarkan kepada pekerja atas jasa pelayanannya kepada pemberi kerja atau perusahaan. Dalam kajian ilmu-ilmu fiqih, upah atau ujrah memiliki aturan yang sangat ketat, hal ini dilakukan untuk menghindari kerugian antara kedua pihak. Oleh karena itu, sistem pengupahan yang 
baik harus berasaskan prinsip keadilan antara penerima kerja dan pemberi kerja. Agar menciptakan kesejahteraan dan terhidar dari kesenjangan sosial.

Menurut Benham upah merupakan biaya yang dikeluarkan oleh pemberi kerja kepada penerima kerja atas layanan yang diberikan berdasarkan kontrak kerja ${ }^{1}$. Dalam ujrah haruslah melalui akad dan dilandaskan atas kerelaan oleh kedua belah pihak ${ }^{2}$ agar sistem ini sah. Sementara menurut Taqyudin An-Nabhani ujrah adalah kewajiban atas pemanfaatan layanan berdasarkan perjanjian. Oleh karena itu, untuk mempekerjakan seorang, kita perlu terlebih dahulu menentukan jenis pekerjaan, waktu pekerjaan, besaran upah dan tanggung jawabnya. Sebab jika hal tersebut tidak dijelaskan kepada penerima kerja maka hukumnya akan menjadi rusak atau tidak sah.

Desa Tinombala Barat memiliki perkebunan dan lahan pertanian yang cukup subur. Situasi ini memberikan kesempatan kerja bagi penduduk desa di Tinombala Barat sebagai buruh tani. Sistem Derep Pari digunakan selama musim panen padi karena sebagian besar penduduk desa di Tinombala Barat adalah pekerja sementara. Ketika musim panen di desa berakhir, mereka akan pergi ke tempat lain untuk mencari musim panen padi di daerah lain. Pemberian upah pada sistem Ini akan diberikan setelah pekerjaan selesai. Dalam perspektif hukum Islam, pengupahan harus berdasarkan kesepakatan awal dan mewakili keadilan, sehingga tercipta keseimbangan hak-hak kerja. Sebagaimana firman Allah swt. dalam QS An-Nisa ayat 135 "Wahai orangorang yang beriman, jadilah kamu orang yang benar-benar penegak keadilan, menjadi saksi karena Allah biarpun terhadap dirimu sendiri atau ibu bapak dan kaum kerabatmu....." 3 . Dalam ayat ini, Allah memerintahkan orang-orang beriman untuk selalu bersikap adil ketika bersaksi kepada siapa pun baik kepada dirinya, keluarganya, sahabatnya tanpa memandang status sosialnya.

Upah merupakan isu yang sangat sensitif, sementara Islam tidak secara jelas menyebutkan bagaimana sistem pengupahan dan berapa batasan upah minimum. Islam hanya menjelaskan bahwa orang yang bekerja harus menerima upah sebagai

\footnotetext{
${ }^{1}$ Afzalur Rahman, Doktrin Ekonomi Islam Jilid II (Yogyakarta: PT Dana Bhakti Wakaf, 1995), 361.

${ }^{2}$ Hendi Suhendi, Fiqih Muamalah (Jakarta: PT. Raja Grafindo, 2011), 113.

${ }^{3}$ Departemen Agama RI, Al-Quran Tajwid Dan Terjemah, 10th ed. (Bandung: CV Diponegoro,
} 2010), 100. 
imbalan atau jasa untuk bekerja, dan menganjurkan agar upah dibayarkan sesegera mungkin sesuai dengan kesepakatan awal. Dari uraian tersebut, penulis tertarik untuk mengkaji lebih dalam tentang sistem pengupahan dalam praktik derep pari di desa Tinombala Barat dan bagaimana pandangan Islam terhadapnya.

B. HASIL DAN PEMBAHASAN

1. Pelaksanaan Sistem Bawon dalam praktik Derep Pari di Desa Tinombala Barat

Lahan pertanian memegang peranan penting bagi masyarakat Desa Tinombala Barat, karena rendahnya tingkat pendidikan sosial, keterampilan dan pengalaman, sehingga mereka terpaksa melakukan pekerjaan pertanian. Kegiatan atau praktik derep pari ini sudah lama dilakukan oleh masyarakat Desa Tinombala Barat sejak kedatangan mereka di daerah tersebut. Karena mayoritas masyarakat adalah penduduk transmigrasi dari pulau jawa dan dilakukan dari dulu hingga sekarang.

Derep Pari adalah sistem pengupahan kepada buruh tani padi dengan upah berupa bawon. bawon adalah sebutan untuk upah buruh tani bukan berbentuk uang melainkan bagian dari hasil panen (gabah atau padi). Diawali saat musim panen padi telah tiba atau padi telah berumur enam bulan. Pemilik lahan akan membutuhkan jasa buruh panen. Karena tidak memungkinkan bagi pemilik lahan untuk memanennya sendiri mengingat begitu rumit dan membutuhkan kesabaran dalam proses memanen padi. Memanen padi biasanya melibatkan dua langkah: langkah pertama adalah memotong tanaman dan kemudian memanennya di satu tempat. Kemudian pisahkan butir beras dari batangnya dan masukkan ke dalam karung. Setelah semua tahapan tahapan dalam memanen padi selesai dikerjakan maka pemilik lahan langsung memberikan upah atau bagian tertentu dari hasil panen kepada buruh tani. Dari hasil wawancara dengan bapak Hudi (buruh tani) :

"Upah buruh dibayarkan setelah pekerjaannya selesai, dalam sistem derep pari dalam melakukan pekerjaan dilakukan dengan cara individu maupun kelompok, namun yang sering dilakukan yaitu dengan kelompok atau biasa disebut sistem borongan. Lebih lanjut beliau menambahkan dalam sistem derep pari ini, upah 
yang diterima oleh para buruh tergantung dari jumlah hasil panen. Tidak ada ketetapan jumlah upah seperti buruh harian."

Dari penjelasan diatas menggambarkan bahwa sistem atau praktik derep pari ini biasanya dilakukan dengan sistem borongan atau secara berkelompok. Kemudian dalam masalah pengupahan. Upah buruh tani ini diberikan setelah pekerjaannya selesai. Dari hasil wawancara dengan bapak wagiman (buruh tani) :

"Dalam sistem pengupahan dari praktik derep pari ini biasanya hasil kesepakatan antara pemilik lahan dan pemborong. Pembagian yang umum dipakai oleh masyarakat adalah 1:7. Tetapi biasanya jika hasil panen lebih banyak dari biasanya pemilik lahan akan memeberikan tambahan berdasarkan sukarela." ${ }^{5}$

Dari penjelasan diatas bisa disimpulkan bahwa upah adalah kesepakatan antara pemilik lahan dan pemborong (buruh tani) mengenai jumlah upah yang diterima biasanya adalah dengan perbandingan 1:7 artinya jika pemilik lahan mendapatkan 7 karung gabah makan buruh mendapatkan 1 karung gabah serta akan ditambah oleh pemilik lahan dengan sukarela. Ditambahkan lagi oleh bapak Muadzin (pemilik lahan):

"Dalam penentuan upah tergantung dari kesepakatan dan cara kerjanya. Pada umumya derep pari dilakukan saat panen padi saja. Para buruh tidak ikut merawat dari saat masa tanam. Maka yang dipakai 1:7. Tetapi jika ikut dari mulai saat tanam biasanya yang dipakai 1:3."6

Dari uraian diatas dapat disimpulkan bahwa penentuan jumlah upah itu juga berdasarkan cara kerjanya artinya kalau jika bekerja saat panen maka pemberian upahnya dengan perbandingan 1:7, jika pemilik lahan mendapat 7 karung maka 1 karung untuk buruh tani. Namun jika ikut merawat dari masa menanam maka pemberian upahnya dengan perbandingan 1:3, jika pemilik lahan mendapatkan 3 karung maka 1 karung untuk buruh taninya. Dalam sistem atau praktik derep pari di Desa Tinombala Barat dalam memperkerjakan seorang buruh, pemilik lahan lebih melihat dari faktor usia, kemampuan fisik dan jenis kelamin. Selain itu pemilik lahan dan buruh tidak melakukan perjanjian secara tertulis, hanya melakukan perjanjian

\footnotetext{
${ }^{4}$ Bapak Hudi, Buruh Tani, Wawancara, Tanggal 10 Juli 2017

${ }^{5}$ Bapak Wagiman, Buruh Tani, Wawancara, Tanggal 23 Juli 2017

${ }^{6}$ Bapak Muadzin, pemilik lahan, Wawancara, Tanggal 20 Juli 2017
} 
secara lisan tanpa adanya saksi sehingga tidak mempunyai kekuatan hukum. Sebagaimana diterangkan oleh bapak Muadzin (pemilik lahan):

"Ketika saya menandatangani perjanjian dengan pekerja atau kontraktor, saya hanya menggunakan perjanjian lisan dan saya tidak perlu pergi ke aparat desa. Selain itu, menurut saya, terlalu sulit untuk menulis di atas kertas, asalkan sudah setuju bekerja, hal ini sudah menjadi kebiasaan orang di sini."

Sehingga dalam bekerja pemilik lahan tidak mengadakan suatu perjanjian tertulis dengan para buruh hanya melakukan perjanjian secara lisan saja. Selain itu, dalam memperkerjakan seorang buruh pemilik lahan harus melihat dari faktor usia, kemampuan fisik dan jenis kelamin seorang buruh. bapak kamsono (buruh tani) mengatakan bahwa "Dalam bekerja kami tidak melakukan perjanjian secara tertulis dengan pihak pemilik lahan, yang penting kami sudah tau kalau upah kami sekian, kerjanya juga sudah ditau, sudah menjadi kebiasaan kami disini kalau bekerja tidak ada perjanjian tertulis." Ditambah lagi oleh bapak yani (buruh tani), "Tidak penting bagi kami masalah perjanjian itu ditulis atau tidak, yang penting kami sudah dapat pekerjaan dan dapat upah oleh pemilik lahan sesuai dengan perjanjian kami dengan pemilik lahan."9 Sehingga dapat diketahui bahwa para buruh bekerja tidak melakukan perjanjian secara tertulis dengan pemilik lahan, yang terpenting mereka sudah mengetahui besaran upah yang akan diterima, sebab mereka menganggap bahwa perjanjian secara lisan tersebut sudah menjadi kebiasaan dari dahulu dan berlaku sampai sekarang. Padahal perjanjian yang baik adalah yang tertulis, sehingga nantinya secara hukum dapat dipertanggungjawabkan. Misalnya, Jika terdapat wanprestasi diantara dua belah pihak, maka penanganannya dapat dilakukan melalui jalur hukum. Sementara jika perjanjian hanya melalui lisan, maka sulit untuk meminta pertanggung jawaban secara hukum. Hal ini terjadi, karena kurangnya pengetahuan masyarakat di desa tersebut serta kurangnya keterampilan dan keahlian yang dimiliki.

\footnotetext{
${ }^{7}$ Bapak Muadzin, pemilik lahan, Wawancara, Tanggal 20 Juli 2017

${ }^{8}$ Bapak Kamsono, Buruh Tani, Wawancara, Tanggal 21 Juli 2017

${ }^{9}$ Bapak Yani, Buruh Tani, Wawancara, Tanggal 22 Juli 2017
} 
Berkaitan dengan sistem kerja yang ada dalam praktik derep pari ini mempunyai sistem kerja borongan dan individu.yang dimaksud dengan sistem kerja individu dan borongan adalah sebagai berikut :

a. Sistem individu adalah buruh yang mendapatkan upahnya dikerjakan secara perseorangan. Artinya berapapun yang ia dapatkan itulah hasil dari kerjanya sendiri. Dan biasanya dalam sistem kerjanya membutuhkan waktu yang lama dalam menyelesaikan pekerjaannya;

b. Sedang sistem borongan adalah buruh yang mendapatkan upahnya yang dikerjakan secara bersama - sama. Dan biasanya dalam menyelesaikan pekerjaannya lebih cepat.

Cuaca sering menjadi kendala bagi pekerja pertanian dan pemilik tanah.. Sebab "kalau waktu panen musim hujan proses panen padinya lebih lama selesainya karena kalau hujan turun otomatis berhenti memanennya. belum lagi terendam banjir padi akan busuk otomatis berpengaruh sama hasil panen"10. Yang dapat mempengaruhi besaran upah buruh tani.

\section{Tinjauan Hukum Islam Terhadap Praktik Derep Pari Di Desa Tinombala Barat}

Sesungguhnya pekerja hanya berhak atas upah jika mereka menyelesaikan pekerjaannya dengan benar dan sesuai dengan kesepakatan, karena umat Islam mematuhi ketentuan di antara mereka, kecuali ketentuan yang melarang hukum yang menjadikannya tidak sah. Misalnya membolos kerja, maka upahnya harus dipotong, karena setiap hak ada hubungannya dengan kewajiban. Selama ia menerima upah penuh, maka harus memenuhi kewajibannya. Sehingga hal Ini harus ditentukan dalam perjanjian kerja yang menjelaskan semua hak dan kewajiban kedua belah pihak. ${ }^{11}$

Upah merupakan faktor terpenting, karena selain menciptakan kondisi yang menguntungkan, upah juga menentukan kinerja pekerja/buruh. Selain itu, upah juga dapat digunakan sebagai insentif bagi pekerja/buruh untuk bekerja. Oleh karena itu,

${ }^{10}$ Bapak Muadzin.pemilik lahan, Wawancara, Tanggal 20 Juli 2017

${ }^{11}$ Yusuf Qaradhawi, Peran Nilai Dan Moral Dalam Perekonomian Islam, trans. Didin Hafiduddin, Setiawan Budiutomo, and Aunur Rofiq (Jakarta: Robbani Press, 2001), 232. 
memastikan upah yang layak mempengaruhi produktivitas pekerja. Apa yang dilakukan pekerja pada tingkat upah tetap, maka pekerjaan yang dibayar selesai. Di sisi lain, ketidakseimbangan antara jenis pekerjaan dan tingkat upah yang dibayarkan mempengaruhi kinerja pekerja. Dalam Peraturan Pemerintah Nomor 5 Tahun 2003 tentang Upah Minimum Regional mengumumkan adanya hak dan kewajiban antara pekerja dan pengusaha. Berdasarkan hak dan kewajiban tersebut, pekerja wajib bekerja dan berhak atas iurannya, yaitu upahnya.

Hukum Islam telah mengatur bahwa perjanjian kerja harus menguntungkan kedua belah pihak. Sehingga tidak boleh ada penindasan dan penghinaan di dalamnya. Transaksi ujrah yang dilakukan harus sesuai dengan prinsip-prinsip dasar transaksi ujrah. Diantaranya, jasa yang diberikan meliputi jasa legal bukan illegal, memenuhi syarat-syarat transaksi yang efektif, yaitu orang yang melakukan transaksi harus dapat membedakan yang baik dan yang buruk, dan harus didasarkan pada kebahagiaan. Tidak boleh ada paksaan dari pihak manapun. Pelaksanaan ujrah juga harus memiliki aturan yang jelas tentang jenis pekerjaan, masa kerja, upah, dan pekerjaan fisik yang dilakukan agar mendapatkan imbalan yang cukup.

Suatu akad dikatakan sah apabila telah terpenuhi rukunnya, karena tanpanya maka akad yang dilakukan tidak sah menurut syariat Islam. Ujrah merupakan bagian dari akad al-ijarah dalam aspek jasa atau ijarah yang bersifat pekerjaan. ${ }^{12}$ Menurut Imam Hanafiyah rukun ijarah hanya ijab dan qabul, sedangkan aturan lainnya masuk dalam syarat ijarah. Adapun menurut jumhur ulama rukun ijarah ada empat: ${ }^{13}$

a. Dua orang yang berakad/al-'aqidayn: pihak yang memberi pekerjaan atau pemberi upah disebut mustajir dan pihak pekerja atau penerima upah disebut dengan ajir. Dalam praktik Derep Pari mustajir merupakan pemilik lahan yang menyewa jasa seseorang untuk membantu memanen padi sedangkan ajir merupakan buruh tani yang di pekerjakan ketika musim panen tiba.

b. Upah/ Ujrah: Upah merupakan imbalan atau iwadh dari suatu pekerjaan yang telah dilakukan, pembayaran upah boleh berupa uang dan boleh berupa

\footnotetext{
${ }^{12}$ Abu Azam al Hadi, Fikih Muamalah Kontemporer, 1st ed. (Depok: Rajawali Pers, 2019), 84.

${ }^{13}$ Siah Khosyi'ah, Fiqh Muamalah Perbandingan (Bandung: Pustaka Setia, 2014), 142-143.
} 
benda. Upah atau imbalan harus jelas dengan ketentuan awal yang telah disepakati. Pemilik lahan melakukan kesepakatan dengan pembagian 1:7 jika pekerjaan dilakukan saat panen saja, dengan perjanjian jika panen melimpah maka akan memberikan bonus lebih pada pekerja. Pada praktik ini juga telah disepakati bahwa upah yang diberikan berbentuk barang yaitu senilai 1:7 dari hasil panen.

c. Sighat (ijab dan qabul): kesepakatan merupakan suatu yang penting sebagai bentuk dari persetujuan dari kedua pihak yang bertransaksi. Dalam hal praktik di Desa ini ijab dan qabul antar pihak telah terlaksana dengan menyebutkan seluruh klausa persyaratan diawal dan keduanya saling menyetujui meskipun masih berbentuk lisan.

d. Manfaat atau Objek: Manfaat jika berhubungan dengan ijarah pada aspek sewa sedangkan objek dalam ijarah pada aspek jasa ialah pekerjaan. Pekerjaan haruslah jelas dan tidak melanggar syariat untuk menghindari timbulnya perselisihan kedepannya. Hali ini telah dilakukan oleh pemilik lahan dengan menjelaskan bahwa tugas dari pekerja ialah memotong tanaman dan kemudian memanennya di satu tempat. Kemudian pisahkan butir beras dari batangnya dan masukkan ke dalam karung.

Islam merupakan agama universal, di mana seluruh permasalahan di muka bumi dapat di selesaikan, terutama masalah pengupahan. Sebab upah merupakan salah satu indikator kemajuan suatu perusahaan, artinya jika perusahaan mampu menberikan upah yang tinggi maka perusahaan tersebut dianggap besar. Dalam suatu perusahaan, upah merupakan hak yang harus diterima oleh karyawan, dan upah merupakan pemicu terjalinnya hubungan yang baik dan harmonis antara karyawan dengan manajemen.

Dalam surah Al-Baqarah ayat 233 Allah menegaskan bahwa setiap usaha atau pekerjaan pasti akan ada imbalannya. “.....Dan jika kamu ingin kamu dan anakmu disusukan oleh orang lain, maka tidak ada dosa bagimu apabila kamu memberikan pembayaran menurut yang patut...." ${ }^{14}$ Islam juga memerintahkan agar membayar upah sesegera mungkin sebelum keringat para pekerja kering, artinya jika pekerjaan

${ }^{14}$ Departemen Agama RI, Al-Quran Tajwid Dan Terjemah, 301. 
buruh suadah selesai maka wajib diberikan upah kepada mereka sesegera mungkin. Rasulullah saw. bersabda "Berikanlah kepada pekerja itu upahnya sebelum kering keringatnya."(HR Ibnu Majah) ${ }^{15}$. Sehingga Islam juga memerintahkan para pemberi kerja untuk membayar upah para pekerjanya secepat mungkin sebagai bentuk penghargaan. Oleh karena itu, pekerja yang dipaksa bekerja dan menerima upah yang rendah berikutnya secara alami pemberi kerja berkewajiban untuk memenuhi kekurangan upahnya.

Setiap pekerja mengharapkan agar upahnya segera dibayarkan. Karena setiap pekerja pasti membutuhkan berbagai kebutuhan. Sehingga tidak dibayarnya upah dapat menyebabkan kesulitan ekonomi. Sebagaimana sabda Rasulullah saw.

" ada tiga golongan yang aku jadi musuh mereka pada hari kiamat. Sedangkan siapa yang aku jadi musuhnya, pasti aku akan mengalahkannya pada hari kiamat; 1. Seorang yang memberi (sesuatu) karena aku, kemudian dia berkhianat. 2. Seorang yang menjual orang merdeka dan dia makan harganya. 3. Seorang yang memperkejakan seorang buruh dan buruh tersebut sudah memenuhi kewajibannya tetapi dia tidak memenuhi upahnya". (HR. Ibnu Majah $)^{16}$

Hadis di atas menekankan untuk sangat berhati-hati dengan waktu pembayaran upah. Penundaan upah dikategorikan sebagai tindakan tirani dan termasuk musuh Allah dan Rasul-Nya pada hari kiamat. Sehingga, dalam hal ini upah tidak dipandang berdasarkan status sosial, jenis kelamin dan pendidikannya, tetapi dari besarnya tanggungjawab dari pekerjaan tersebut. Menurut Rafik Issa Beekum, perusahaan yang menjamin distribusi kekayaan dan pendapatan, harus adil dalam menguraikan lima prinsip yang dapat digunakan untuk memastikan distribusi keuntungan. Seperti, setiap orang akan mendapat bagian berdasarkan usahanya dan jasa yang diberikannya. Jika memperhatikan hal tersebut, maka pekerja dapat bekerja dengan nyaman, karena kerja keras mereka sangat dihargai oleh perusahaan. ${ }^{17}$

\footnotetext{
${ }^{15}$ Abu Abdillah Muhammad bin Yazid Al-Qazwini, "Sunan Ibnu Majah," (Kairo: Dar Ihyaul Kutub Arabi, 2018), No. 2443.

${ }^{16}$ Al-Qazwini, No. 2442.

${ }^{17}$ Rafik Issa Beekum, Etika Bisnis Islami (Jakarta: Pustaka Pelajar, 2004), 185.
} 
Hukum Islam menganjurkan agar upah yang diterima oleh pekerja mengikuti energi yang telah diberikan. Mengingat situasi sosial ekonomi para pekerja, yang menyebabkan mereka tidak boleh tertipu atau mengalami kerugian karena dalam posisi ekonomi lemah. Sehingga upah harus dibayarkan sesuai dengan keterampilan dan kemampuan masing-masing pekerja. Pada saat itu, dapat dikatakan bahwa pekerja berhak atas upah sesuai dengan keahlian dan kemampuannya. Sebagimana dalam kaidah usul fiqh bahwa kebiasaan (adat) bisa dijadikan hukum selama tidak melanggar hukum Islam. Jika dikaitkan dengan sistem derep pari, maka praktik pengupahan ini tidak menyalahi aturan syariat, karena sistem ini merupakan kebiasaan masyarakat di desa tinombala barat yang dilakukan sejak lama, serta tidak ada unsur kezaliman di dalamnya.

\section{KESIMPULAN}

Praktik Derep pari adalah proses memanen padi yang dilakukan oleh seorang buruh tani dengan sistem upah berupa bagian dari hasil panen, berupa gabah. Sistem Bawon pada praktik derep pari ini berdasarkan pada jumlah hasil panen setelah pekerjaannya selesai dikerjakan dan sesuai dengan kesepakatan awal dan akan ada tambahan jumlah upah dari pemilik lahan, tetapi itu sifatnya suka rela tidak ada paksaan atas dasar keikhlasan. Pembagian upahnya jika dikerjakan dalam masa penen saja maka pembagiaanya 1:7 jika pemilik lahan mendapatkan 7 karung gabah maka 1 karung gabah untuk buruh tani. Tetapi jika buruh ikut merawat dari saat mulai tanam maka pembagiaannya 1:3, Jika pemilik lahan mendapatkan 3 karung gabah maka 1 karung gabah untuk buruh tani. Dalam sistem kerjanya praktik ini terdapat dua cara yaitu individu dan borongan.

Praktik Derep pari di desa tinombala barat dapat diklasifikasikan sebagai sistem yang sah secara Islam, dengan mempertimbangkan bahwa objek dan subjeknya, tidak melanggar norma-norma Islam dan syarat sah suatu akad. Dilihat dari konsepnya sistem derep pari telah memenuhi aspek keadilan di mana tidak ada pihak yang merasa di rugikan dan terzalimi. Selain itu, tidak di temukan suatu penundaan pembayaran upah yang termasuk bentuk ketidakadilan. 


\section{REFERENSI}

Abu Azam al Hadi. (2019). Fikih Muamalah Kontemporer (1st ed.). Depok: Rajawali Pers.

Al-Qazwini, A. A. M. bin Y. (2018). Sunan Ibnu Majah. In 817. Kairo: Dar Ihyaul Kutub Arabi.

Beekum, R. I. (2004). Etika Bisnis Islami. Jakarta: Pustaka Pelajar.

Departemen Agama RI. (2010). Al-Quran Tajwid dan Terjemah (10th ed.). Bandung: CV Diponegoro.

Khosyi'ah, S. (2014). Fiqh Muamalah Perbandingan. Bandung: Pustaka Setia.

Qaradhawi, Y. (2001). Peran Nilai dan Moral dalam Perekonomian Islam (D. Hafiduddin, S. Budiutomo, \& A. Rofiq, trans.). Jakarta: Robbani Press.

Rahman, A. (1995). Doktrin Ekonomi Islam Jilid II. Yogyakarta: PT Dana Bhakti Wakaf.

Suhendi, H. (2011). Fiqih Muamalah. Jakarta: PT. Raja Grafindo. 
